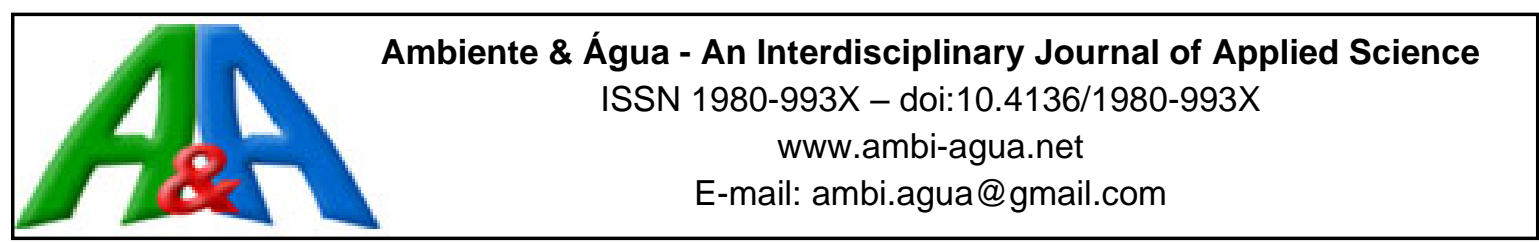

\title{
Influence of sand addition in the early stage retention of fine sludge dewatering by geotextile
}

\author{
ARTICLES doi:10.4136/ambi-agua.2527
}

Received: 04 Feb. 2020; Accepted: 08 May 2020

\author{
Gabriel Luis Anibal de Oliveira*iD; Delma de Mattos Vidal \\ Departamento de Geotecnia. Instituto Tecnológico de Aeronáutica (ITA), Praça Marechal Eduardo Gomes, \\ n 50, CEP: 12228-900, São José dos Campos, SP, Brazil. E-mail: delma@ita.br \\ *Corresponding author. E-mail: olliveira.g.l.a@gmail.com
}

\begin{abstract}
The need to investigate viable methods to facilitate correct disposal of high-water content waste is immediate in the scenario of water source degradation. In this context, Closed Geotextile Systems (CGS) have shown promise for dewatering a variety of high water-content sediments, aiming to reduce the waste final volume, encapsulating particles, and at the same time allowing fluid drainage. Especially in Water Treatment Plants, the geotextiles generally employed in these systems have good tensile strength and rigidity to support mechanical solicitations and hydraulic properties that warrant good drainage conditions. In these applications, the geotextile element should assure the waste confinement and retention of some particles that will form a filter cake which will control internal flow conditions. The present work investigated how small portions of sand influence fine-particle retention. The sludge used consisted of a mixture of filtered water with two well-defined fractions of ground quartz: FG, a silt and CG, a fine sand. The results show that small amounts of sand are capable of leading to the formation of a pre-filter, even if the maximum diameter of the fine particles is much less than the geotextile filtration opening size. The test results indicate that the retention efficiency gradually increases as CG increases in the solution, up to a fraction of CG close to $14 \%$, which represents only $0.7 \%$ of the total solution mass. The increase in particle retention was directly proportional to the increase in the GC fraction until reaching the filtration efficiency of approximately $72 \%$ where it stabilizes.
\end{abstract}

Keywords: environmental protection, filtration, geosynthetics

\section{Influência da adição de areia na retenção inicial do desaguamento de lodos finos por geotêxtil}

\section{RESUMO}

A necessidade de investigar métodos para facilitar a correta disposição de resíduos com alto teor de água faz-se eminente frente ao cenário de degradação dos corpos d'água. Nesse contexto, o uso de Sistemas Confinante em Geotêxteis (SCG) têm se mostrado promissor no desaguamento de uma variedade de sedimentos com alto teor de água, objetivando reduzir seu volume final, encapsulando as partículas e permitindo a drenagem do fluido. Especialmente em Estações de Tratamento de Água, os geotêxteis empregados nesses sistemas tem boa resistência à tração e rigidez para suportar solicitações mecânicas; e propriedades hidráulicas que garantem boa drenagem. Nessas aplicações, o elemento geotêxtil deve garantir o confinamento dos 
resíduos e a retenção de algumas partículas que formarão a torta de filtro, elemento que controlará as condições internas de fluxo. O presente trabalho investigou como pequenas porções de areia influenciam a retenção de partículas finas. A lama utilizado consistiu de uma mistura de água filtrada com duas frações bem definidas de quartzo moído: FG, um silte e CG, uma areia fina. Os resultados mostram que pequenas quantidades de areia conseguem iniciar a formação de pré-filtro, mesmo que o diâmetro máximo das partículas finas seja menor que o tamanho da abertura de filtração do geotêxtil. Os resultados indicam que a eficiência da retenção aumenta gradualmente à medida que CG aumenta na solução, até uma fração de CG próxima a $14 \%$, o que representa apenas $0,7 \%$ da solução total. $\mathrm{O}$ aumento na retenção de partículas foi diretamente proporcional ao aumento da fração $\mathrm{GC}$ até atingir a eficiência de filtração de aproximadamente $72 \%$, onde se estabiliza.

Palavras-chave: filtração, geossintéticos, proteção ambiental.

\section{INTRODUCTION}

Waste management is a challenge experienced worldwide. Among the residues generated by human activity, high water-content residues represent an additional risk to the quality of water sources, as they can be easily dumped (Biswas et al., 2006). These wastes originate from several activities, such as dredging projects, mining processes, paper mills, agriculture, industry, and water treatment plants (Lawson, 2008).

These residues, when released in water bodies without pre-treatment, can cause environmental impacts such as increased water solids and toxic metals, increased turbidity, color, and altered dissolved oxygen levels (Di Bernardo and Dantas, 2005).

A first approach to treating these high-water content sediments is thickening them to increase the solids content of the sludge. The process usually involves the removal of excess water by decanting and the concentration of the solids by settling their volume by removing free water from sludge to decrease transportation and disposal costs. Several methods can be used to achieve this reduction and can be divided into two groups: natural methods, such as drying beds and sedimentation lagoons, and mechanical methods, such as filter press, vacuum filtration, and centrifuges (Andreoli et al., 2001; Reali, 1999).

To improve the dewatering of sludge with high water content, chemical conditioning is commonly used to change the sludge properties to facilitate water drainage. The most used conditionings are synthetic ionic or non-ionic polymers, but some other components, such as lime, fly ash, or cellulose, can be added depending on the type of technique used for dewatering (Crittenden et al., 2012; Mines Jr., 2014).

An alternative to conventional treatment of sludge is the use of geotextile closed systems (GCS) to dewater them. Their use has become popular in the past years, as they can provide a safe alternative to dispose of contaminated sediments by allowing dewatering, encasing and isolation of the waste inside the system (Guimarães et al., 2014; Lawson, 2008). The main goal of GCS in the sludge treatment chain is to achieve a volume reduction of the material through a filtration mechanism, allowing water to drain (Bourgès-Gastaud et al., 2014). Due to the complexity of the phenomena involved and the continuous improvement of the technique, many aspects of the problem still need research to better understand the involved mechanism in the GCS dewatering process.

Many factors can influence the dewatering of sediments by GCS, such as geotextile mechanical and hydraulic properties, as well as sludge characteristics like grain-size distribution, initial solid concentration and mineral composition (Segré, 2013). The geotextiles generally employed in these systems have good tensile strength and rigidity to support mechanical solicitations and hydraulic properties that warrant a good drainage condition. In 
these applications, the geotextile element should assure the waste confinement and the retention of some particles that will form a filter cake which controls the internal flow conditions.

Different authors assessed one-directional dewatering processes in bench-scale apparatus, using a variety of sludge and geotextiles, by pressurized column test (Liao And Bhatia, 2005; Driscoll et al., 2016; Ratnayesuraj and Bhatia, 2018), and by falling-head column test (Weggel and Dortch, 2012; Muthukumaran and Ilamparuthi, 2006) and the geotextiles proved to be able to retain sludge particles and maintain reasonable drainage.

Bourgès-Gastaud et al. (2014) presented an experiment on the influence of the clay/silt fraction on the dewatering process with nonwoven geotextiles by pressurized column tests. The increment in the silt fraction shows improvement in the fine-retention capability of the geotextile. That behavior seems promising as an alternative to sludge chemical conditioning. However, it is not trivial to correlate the results obtained for nonwoven geotextile to woven ones, as they have very distinguishable structures and, in general, large pore-size diameters.

The possibility of having sludge with a low percentage of solids, such as those generated in water treatment plants, directly pumped in GCS for dewatering is one of the aspects that deserve more studies due to the simplifications that this process could represent.

The present work investigated how the grain-size distribution variation of the sludge particles affects the effluent flow rate and the solid retention capacity of GCS using a woven geotextile by falling-head dewatering test. A mixture of sand/silt was used with the sand ratio ranging from 0 to $30 \%$. The experiments were carried out in the Geosynthetics Laboratory, situated at Aeronautics Institute of Technology, São José dos Campos, Brazil.

\section{MATERIALS AND METHODS}

\subsection{Geotextile material}

The material used for the dewatering in the experiment was a polypropylene woven geotextile, black in color, properly developed for dewatering applications, shown in Figure1. The geotextile weft is presented in Figure 1a and Figure 1b shows the detail of geotextile fiber overlapping in a perpendicular view. The physical and hydraulic characteristic of the tested sample were mass per unit of area $(\mu)$ of $454 \mathrm{~g} / \mathrm{m}^{2}$ (ISO 9862), thickness $\left(\mathrm{T}_{\mathrm{g}}\right.$ ) of $1.7 \mathrm{~mm}$ (ISO 9863-1) and characteristic opening size (O90) of $240 \mu \mathrm{m}$ (ISO 12956) (ISO, 1988; 2005; 2009; 2010; 2016).

The characteristic opening size of a geotextile is obtained by wet sieving of a special soil, where the geotextile acts as the sieve. Figure 1c presents the original soil grain-size distribution curve and the grain-size distribution curve of the soil passing in the test. The parameter $\mathrm{O}_{90}$ is defined as the $\mathrm{d}_{90}$ of the soil passing curve. Woven geotextiles are considered materials with uniform pore size, having less variability in the pore size than nonwoven geotextiles, so the $\mathrm{O}_{90}$ is assumed as a good estimation for the overall geotextile pore size.

To better understand the geotextile behavior during the test, the water penetration resistance (WPR) of the geotextile face exposed to the flow was determined according to EN 13562 (European Committee, 2000). This test measures the hydraulic load necessary to begin the flow through the geotextile, due to its hydrophobic characteristics, and the results indicate a mean value of $35.8 \mathrm{~mm}$ water column (with a coefficient of variation of $3.6 \%$.) was necessary to overcome the water penetration resistance.

\subsection{Granular material}

To create a controlled sludge with precise grain-size distribution (GSD) curve an industrialized ground-quartz was chosen as the solid material. The ground-quartz is a practically inert material with high hardness, making it less susceptible to abrasion. 


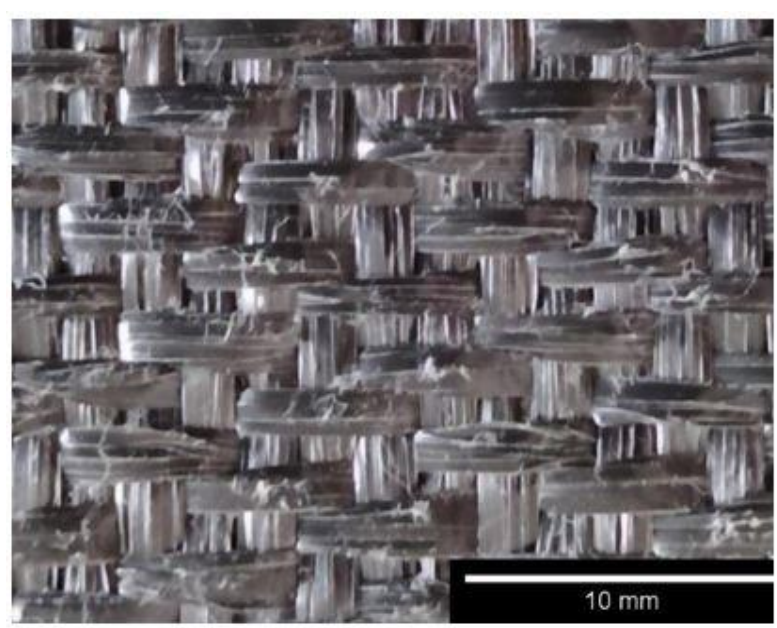

a) Geotextile sample

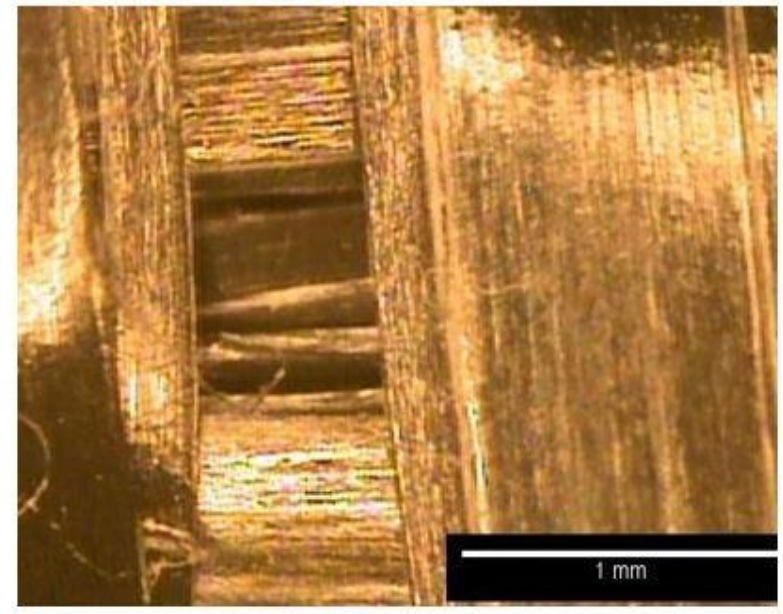

b) Geotextile pore detail

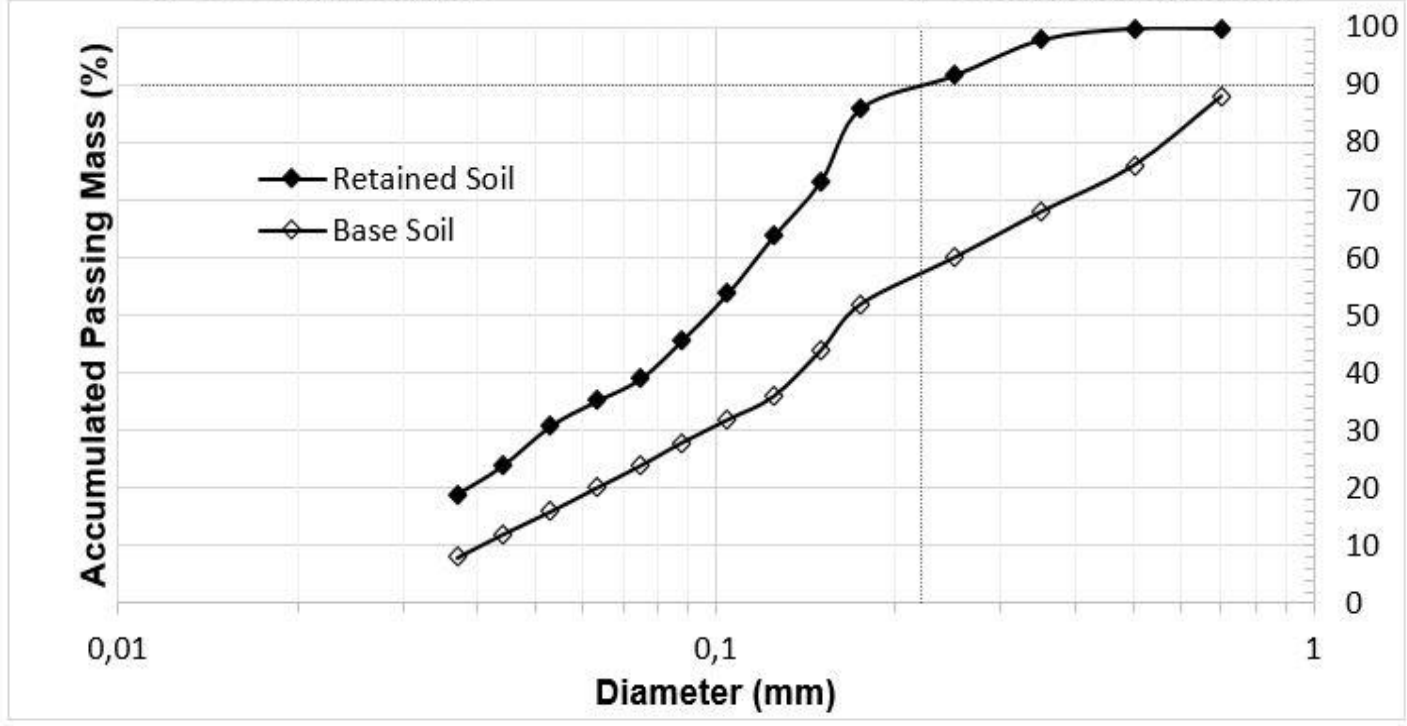

c) Characteristics of opening-size curve

Figure 1. Geotextile pore characteristics.

The ground-quartz specific density was determined according to ABNT NBR NM 52 (ABNT, 2009), obtaining a value of $2.67 \mathrm{~g} / \mathrm{cm}^{3}$. It was separated in two narrow GSDs with water sprinkler and agitation sieving, that is a wet sieving method as described by ISO 2591 1:1988; one denominated FG, classified as silt, used as the solid matrix for the sludge; and one denominated CG, classified as poorly graded fine sand according to ASTM D2487-11 (ASTM, 2011).

The material was wet sieved to remove the small particles created by the crushing process. The fraction retained between sieve \#40 and sieve \#100 compose the CG particles, and the fraction retained between sieves \#100 and \#400 compose the FG particles.

The GSD curves of CG and FG are presented in Figure 2a. The visual aspect of the groundquartz grains, CG and FG, are detailed in Figure 2b and Figure 2c.

Each GSD was characterized by the laser diffraction method according to ISO 13320:2009. FG particles presented a coefficient of uniformity (CU) of 1.67, and characteristics diameter $\mathrm{d}_{85}, \mathrm{~d}_{50}$, and $\mathrm{d}_{15}$ of $72 \mu \mathrm{m}, 53 \mu \mathrm{m}$, and $32 \mu \mathrm{m}$, respectively - the index represents the portion of particles smaller than the corresponding diameter, e.g., $\mathrm{d}_{85}$ is a diameter bigger than $85 \%$ of the particles. CG particles presented a coefficient of uniformity (CU) of 1.39 , and characteristics diameter $\mathrm{d}_{85}, \mathrm{~d}_{50}$, and $\mathrm{d}_{15}$ of $255 \mu \mathrm{m}, 215 \mu \mathrm{m}$, and $130 \mu \mathrm{m}$, respectively. 


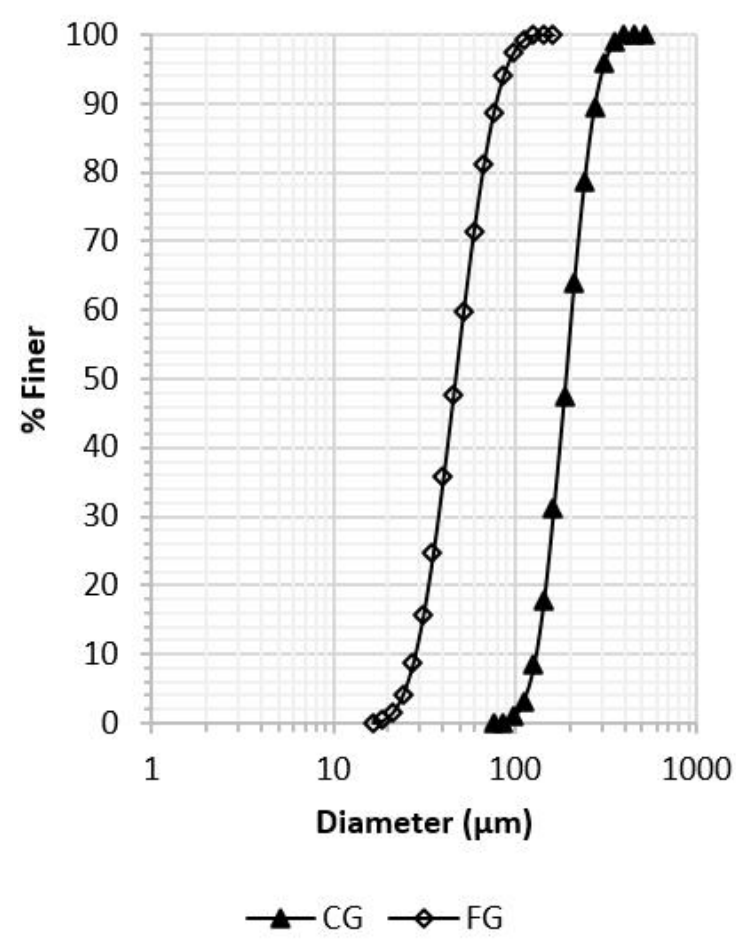

a) GSD of used soils

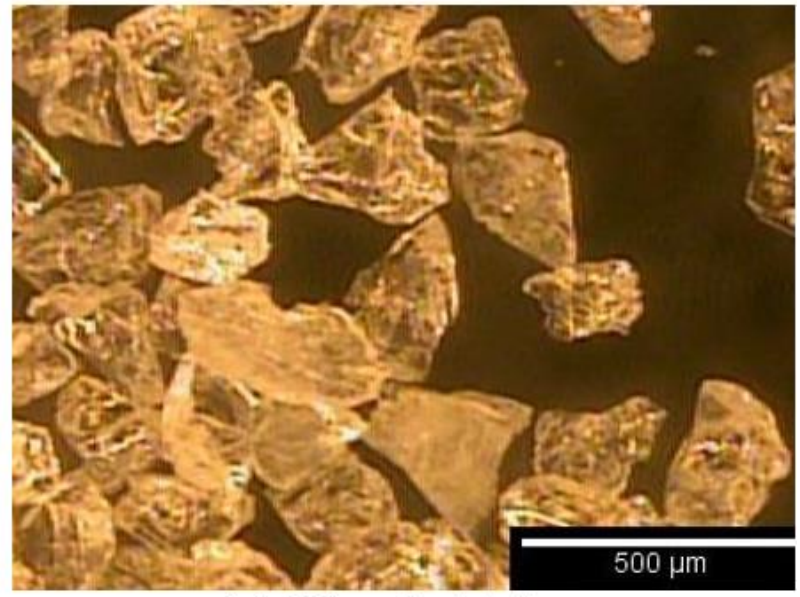

b) CG grain details

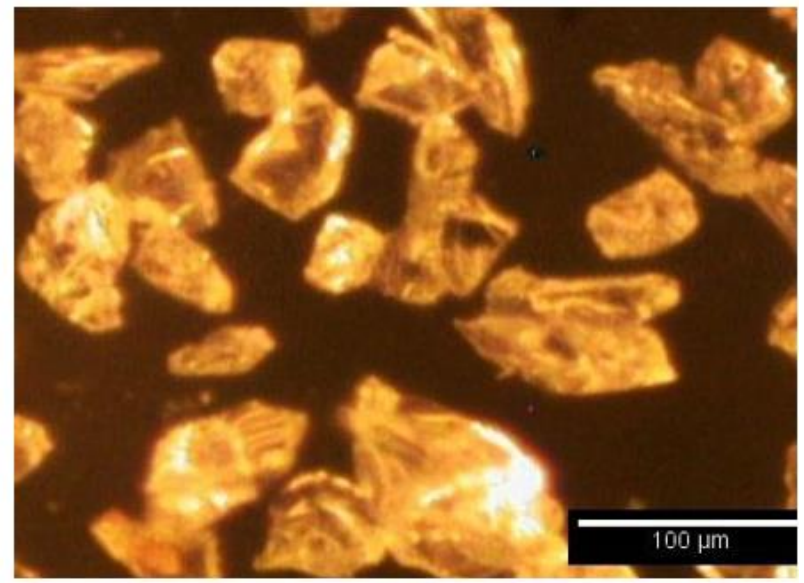

c) FG grain details

Figure 2. $\mathrm{CG}$ and FG particle characteristics.

Those two GSD were selected to provide a material coarse enough to be retained by the geotextile (CG) and a material with a low probability of retention, to simulate the critical condition of fine sludge dewatering. Also, CG is classified as a filter to FG, according to Terzaghi filter criterion (Lambe and Whitman, 1969) for satisfying, simultaneously, Equations 1,2 , and 3 .

$$
\frac{D_{15}}{d_{85}}<5
$$

$4<\frac{D_{15}}{d_{15}}<20$

$\frac{D_{50}}{d_{50}}<25$

Being $\mathrm{D}_{\mathrm{i} \%}(\mathrm{~mm})$ the characteristic diameters of the soil acting as a filter, and $\mathrm{d}_{\mathrm{i}} \%(\mathrm{~mm})$ the characteristic diameters of the soil to be retained.

\subsection{Falling-Head column apparatus}

The apparatus developed is an adaptation of the apparatus used by Weggel and Dortch (2012). It is composed of an acrylic tube with an $83 \mathrm{~mm}$ inner diameter and is $600 \mathrm{~mm}$ high, attached to a grappling system in the bottom end to place the test sample. The grappling system allows us to hold the specimen in a horizontal position without deformation or sagging. Due to the geotextile characteristics, it was not necessary to install a wire mesh in the grappling system. 
The data acquisition is made by connecting the column to a scale with a metallic frame. Also, another scale is placed on the bottom of the column to collect the effluent.

A hydraulic pump attached to a mixing reservoir was used to pump the solution inside the column. To determine the maximum pump flow rate, tree tests were conducted pumping only water to inside the column with its outlet flow blocked by an impermeable membrane indicating a mean value of $267.7 \mathrm{~g} \mathrm{~s}^{-1}$ with a standard error of $1.7 \mathrm{~g} \mathrm{~s}^{-1}$. Figure 3 shows the column test apparatus scheme.

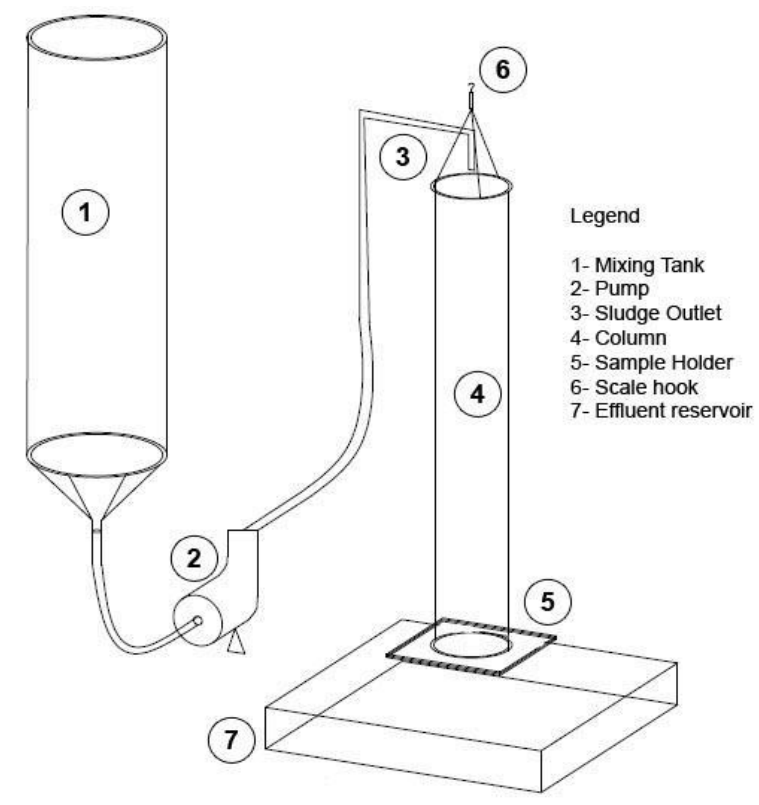

Figure 3. Test apparatus scheme.

\subsection{Testing run protocol and data analysis}

A volume of five liters of the solution was prepared by mixing the correspondent fraction of FG and CG with filtered water to make the sludge with five percent solid content. The resulting sludge was transferred to the mixing tank to be inserted in the column by the pump. Each test run consisted of one single filling and drawdown phase. The effluent was collected at each dewatering phase end. The dewatering end phase was characterized by an evaporation mass loss surpassing the effluent flow rate.

The collected effluent was wet-sieved to recover each portion of FG and CG, as the remaining solution in the mixing tank. The solid material retained in the geotextile specimen was washed and also sieved.

The flow data analysis was restricted to the filling phase and consisted of plotting the passing and retained mass curves over time, then fitting the best linear regression for each one. The behavior of the angular coefficient was analyzed as the portion of CG increased. The solid retention analyzed was based on Filtration Efficiency (FE) (Moo-Young et al., 2002), and Piping Rate (Satyamurthy and Bhatia, 2009), determined by Equations 4 and 5, respectively.

$$
\begin{aligned}
& F E=\frac{T S_{\text {ini }}-T S_{\text {final }}}{T S_{\text {ini }}} \times 100 \\
& P P=\frac{S_{\text {final }}}{A}
\end{aligned}
$$

with FE being the filtration efficiency (\%), PP the piping rate $\left(\mathrm{g} \mathrm{m}^{-2}\right)$, TS the total solids concentration $\left(\mathrm{g} \mathrm{m}^{-3}\right)$; $\mathrm{S}$ the solid mass in the sludge $(\mathrm{g})$, and A the specimen's area exposed to the flow $\left(\mathrm{m}^{2}\right)$. 


\section{RESULTS AND DISCUSSIONS}

\subsection{Initial condition}

A set of seven dewatering tests were carried out. The experiment was designed to investigate how the dewatering flow rate and solids retention behave as the grain-size distribution of the sludge changes slightly. The progressive increment in the coarse fraction of the material was similar to that adopted by Bourgès-Gastaud et al. (2014) in similar work with nonwoven geotextile and a sludge made of a silt-clay mixture.

During the test, the solids concentration of the sludge varied as a response to the pumping process. The difference between the percent solids of the prepared sludge and its volume pumped to the column is shown in Table 1, identified as PS and $\mathrm{PS}_{\text {real }}$, respectively. The same occurs with the intended percentage of CG in the sludge, with PCG being the percentage of CG in the sludge, and $\mathrm{PCG}_{\text {real }}$ the percentage in the pumped volume.

Also, during the sieving process to recover fractions passing or retained of FG and CG, the same granular material can be lost. A total solid loss threshold was fixed at $3 \%$ to discard a test run, as a high solid loss could interfere in the interpretation of the results. Also, the temperature (T) of the sludge was measured and the relation $\mathrm{O}_{90} / \mathrm{D}_{85}$ was calculated.

Table 1. Summary of initial test conditions.

\begin{tabular}{lccccccc}
\hline Test & OS $(\%)$ & PS $_{\text {real }}(\%)$ & PCG $(\%)$ & PCG $_{\text {real }}(\%)$ & Solid Loss $(\%)$ & $\mathrm{T}\left({ }^{\circ} \mathrm{C}\right)$ & $\mathrm{O}_{90} / \mathrm{D}_{85}(\mathrm{~mm})$ \\
\hline F0 & 5 & 4.7 & 0 & 0.0 & 1.3 & 25.4 & 3.3 \\
F3 & 5 & 5.4 & 3 & 2.9 & 1.4 & 20.5 & 3.2 \\
F5 & 5 & 5.4 & 5 & 4.2 & 3.0 & 22.1 & 3.2 \\
F7 & 5 & 5.5 & 7 & 6.5 & 1.8 & 20.6 & 3.1 \\
F9 & 5 & 5.4 & 9 & 9.4 & 1.7 & 22.2 & 3.0 \\
F15 & 5 & 5.3 & 15 & 14.2 & 1.7 & 20.9 & 2.4 \\
F30 & 5 & 5.3 & 30 & 27.0 & 1.4 & 19.0 & 1.4 \\
\hline
\end{tabular}

\subsection{Filling phase dewatering behavior}

The first observed aspect in the experiment was the flow response of the dewatering process with the increment of CG in the sludge for the filling phase. The filling phase consists of the pumping interval to achieve a high of about $50 \mathrm{~mm}$. Figure 4 shows the retained (a) and passing (b) curves for the seven runs. The observed filling phase duration varied from 14 to 18 seconds, implying in different volumes to achieve the intended high.

The slope of the passing mass curves decreases gradually as the PCG increases, indicating a progressive increase in hydraulic head loss caused by particle retention, as shown in Figure 4b. The same behavior is observed with less intensity in the retained mass curves, the difference in intensity is due to the flow rate given by the pump. Also, in Figure $4 \mathrm{~b}$ by the time of five sec. the passing mass curves show distinguishable divergent behavior, indicating how early in the dewatering processes the GSD of the sludge can cause an effect in the flow.

Flow rate decreases mainly by particle retention and consequent filter cake formation that gradually improve the system retention capability. This process evolves through time as shown in Figure 4. The same phenomenon was observed by Muthukumaran and Ilamparuthi (2006), when analyzing the dewatering behavior of clayey dredged sediment and fly ash by the fallinghead dewatering test.

In the F30 run, the flow-rate decreasing trend is no longer observed. As the PSC approaches $15 \%$, the curves seem to approach the same slope. The passing mass curves presented a good linear fit, with R-square varying from 0.969 to 0.989 , enabling analysis by its angular coefficient $\left(\alpha_{P}\right)$. One important aspect of the filling phase is the influence of the GSD on the pumping rate, as the PCG increases the energy loss in the pumping also increases, resulting in a decreasing flow rate. 

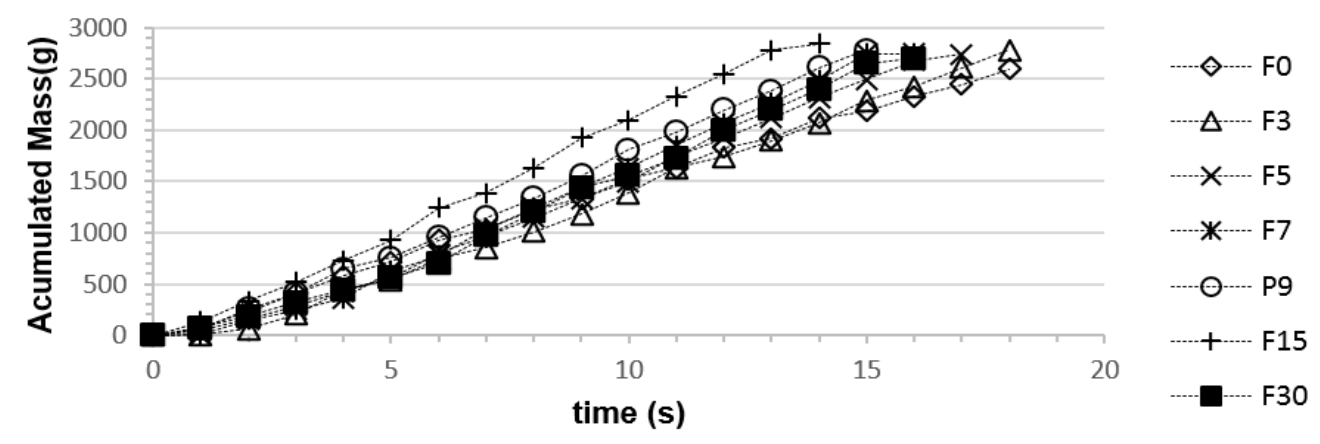

a) Retained Mass

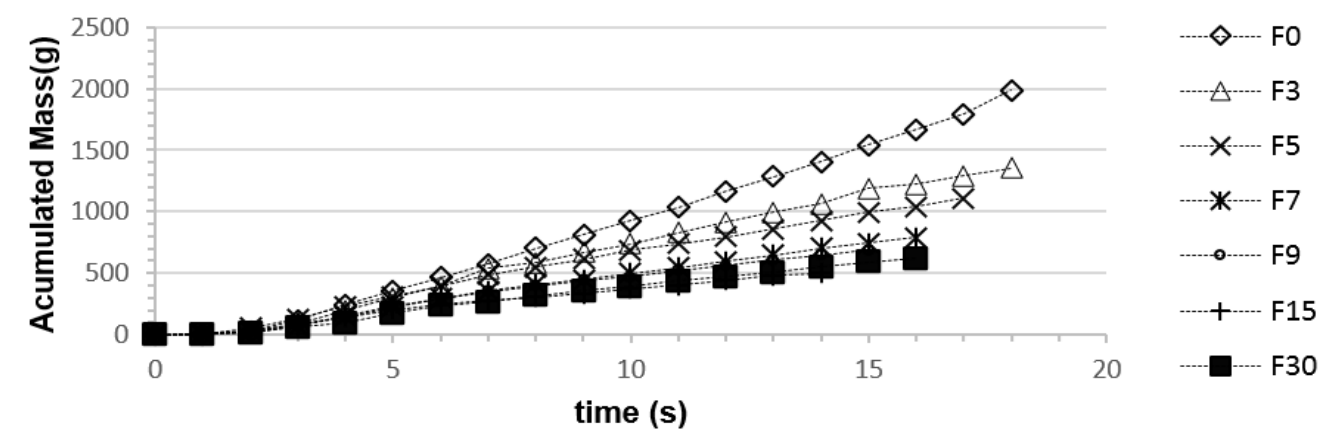

b) Passing Mass

Figure 4. Accumulated mass behavior for different initial PSC on filling phase.

To analyze the effluent flow rate without the interference of this energy loss, the values of $\alpha_{\mathrm{P}}$ of each test were normalized by the total flow rate's slope $\left(\alpha_{\mathrm{T}}\right)$. The $\alpha_{\mathrm{T}}$ parameter was obtained by adding the passing and retained mass data, as its sum should represent the total flow rate pumped to the column, and fitted to the best linear regression. The total mass curves also show a good linear fit with R-square, varying from 0.976 to 0.995 .

Figure 5 shows the resulting values of $\alpha_{\mathrm{P}} / \alpha_{\mathrm{T}}$ as a function of the $\mathrm{PCG}_{\text {real }}$, for small additions of coarse material, the flow rate decreases rapidly, around seven percent of PCG. The observed reduction in $\alpha_{\mathrm{P}} / \alpha_{\mathrm{T}}$ due to the addition of seven percent of CG was $46 \%$, a drop of almost half of the flow rate observed for the scenario with no CG added.

The $\alpha_{\mathrm{P}} / \alpha_{\mathrm{T}}$ stops decreasing from F15 to F30, due to an increase in the CG content in the sludge; hence the portion of fine material is being gradually replaced by coarse material. This replacement decreases the flow resistance, as the overall retained material is more permeable.

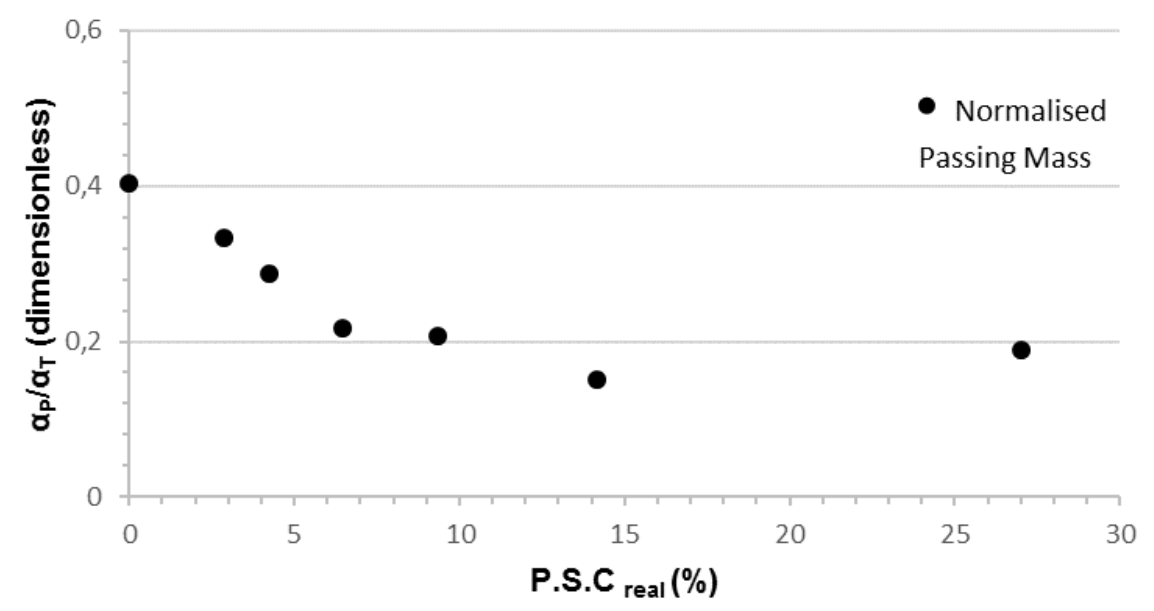

Figure 5. Normalized $\alpha$ values for passing masses. 


\subsection{Solid retention analysis}

The solid retention analysis aimed to quantify how the gradual increase in PCG affected the ability of the geotextile used in this work to retain the solid particles. The Filtration Efficiency, FE compares the initial and final total solids concentration in the sludge (see Equation 1). The piping rate, PP, gives an overview of the sediment loss per geotextile area exposed to the flow (see Equation 2). Both FE and PP were calculated after the dewatering time established in the test. The dewatering time ranged from 60 to $360 \mathrm{~s}$ when the CG fraction increased from 0 to $6 \%$, reaching $1500 \mathrm{~s}$ for testing with $14 \% \mathrm{CG}$ and dropping to $1200 \mathrm{~s}$ with $27 \% \mathrm{CG}$.

Figure 6 shows the observed behavior of the FE (a) and PP (b) as the PCG gradually increases. For the first run, with no PCG addition, the geotextile was barely capable of retaining any quantity of solids presenting a FE of proximally nine percent and PP of $36 \mathrm{~kg} \mathrm{~m}^{-2}$; this behavior is a result of the relationship between the geotextile pore size and the GSD $\left(\mathrm{O}_{90} / \mathrm{d}_{85}=\right.$ 3.3).

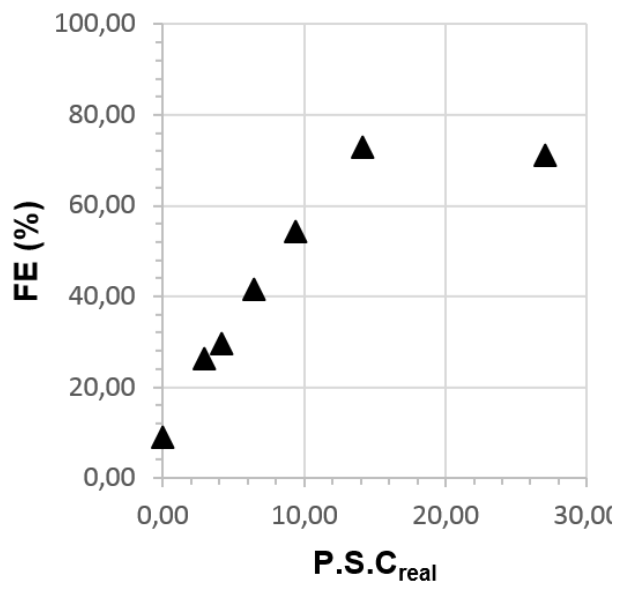

a) Filtration Efficient (FE)

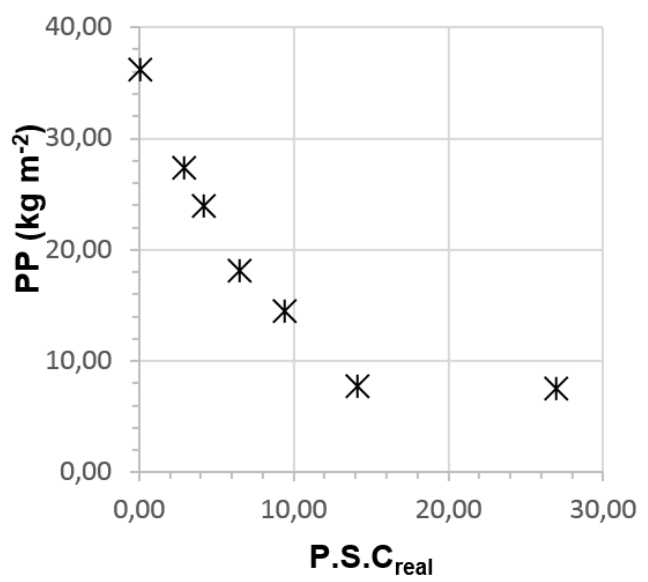

b) Piping rate (PP)

Figure 6. Solid retention analyses.

The gradual increment of PCG results in the improvement of the geotextile solid retention capability. Around $15 \%$ PCG, FE reaches its maximum value of $73 \%$, a considerable increase of almost 8 times, and PP reaches its minimum value of $7.7 \mathrm{~kg} \mathrm{~m}^{-2}$, a 4.7 times reduction in the piping rate for the investigated scenario. Moo-Young et al. (2002) pointed out that geotextile is capable of retaining particles smaller than its pores when analyzing the dewatering process of four different sludges using four woven geotextiles.

The further increase in the PSG beyond $15 \%$ does not result in any improvement in the solid retention performance. When looking at the $\mathrm{d}_{85}$ mixtures used in the test, its values gradually increase as more CG is added, at F15 it is almost half of the size of the geotextile opening size $\mathrm{O}_{90}$, e.g., $\mathrm{O}_{90} / \mathrm{d}_{85} \approx 2.4$, increasing the $\mathrm{d}_{85}$ value does not result in better retention parameters in these tests.

\section{CONCLUSIONS}

This work presents an alternative solution to improve the dewatering of sludge with high water-content by the addition of small amounts of sand to start the formation of the filter-cake. It focused on the observation and analysis of the flow-rate behavior and solid retention capability of a woven geotextile evaluated by a falling-head dewatering test. The tests considered synthetic sludge composed of fine particles (FG) that are not retained by the 
geotextile and a small fraction of coarse particles $(\mathrm{CG})$ that could be retained by the geotextile and could retain the fine particles. The question was not if the coarse fraction could contribute to retention, but how many particles would be necessary to evaluate the viability of that contribution.

Based on the results, it can be concluded that the tested dewatering scenarios show a high sensibility to small changes in the coarse fractions of the sludge. The presence of a small fraction of CG particles can significantly improve particle retention.

This behavior is defined in the early stages of the filling phase as a result of the geotextile pores' particle retention, acting as a stabilizer for the filter cake formation upstream from the geotextile.

The head loss observed in the flow is intrinsically linked to the success of the particle retention. The addition of $14 \%$ of $\mathrm{CG}$, which represents only $0.7 \%$ of the total solution mass, results in a gain of $64 \%$ in the Filtration Efficiency and a reduction of 4.7 times in the observed piping rate. However, there is a limit to the increment of the CG particles, because it does not result in any improvement in the solid retention capability when considering a vertical flow. The gains approach a limit when the relation $\mathrm{O}_{90} / \mathrm{d}_{85}$ nears 2.4 in the tests conducted in this research.

The geotextile applied on the dewatering project must withstand the mechanical and hydraulic stresses imposed by pumping the sludge into the GCS; these mechanical restrictions lead to the use of geotextiles with $\mathrm{O}_{90}$ much larger than the fine particles' diameter, leading to the need for chemically conditioning the sludge. The addition of small portions of coarse material with a diameter near the geotextile $\mathrm{O}_{90}$ looks promising as an alternative sludge conditioning to improve the dewatering process of fine sludge with high water content.

\section{ACKNOWLEDGMENTS}

This study was financed part by the Coordenação de Aperfeiçoamento de Pessoal de Nível Superior - Brasil (CAPES) - Finance Code 001.

\section{REFERENCES}

ANDREOLI, C. V. et al. Resíduos sólidos do saneamento: processamento, reciclagem e disposição final. Rio de Janeiro: RiMa; ABES, 2001. 282p.

ASTM. D2487-11: Standard Practice for Classification of Soils for Engineering Purposes (Unified Soil Classification System). West Conshohocken, PA, 2011 https://dx.doi.org/10.1520/D2487-11

ABNT. Nbr NM 52: Agregado miúdo - Determinação da massa específica e massa específica aparente. Rio de Janeiro, 2009.

BISWAS, A. K. et al. (ed.). Water quality management in the Americas. : Berlin Heidelberg Springer-Verlag, 2006. 298 p.

BOURGÈS-GASTAUD, S.; GUILLAUME S.; FABIENNE S.; NATHALIE T. Nonwoven geotextiles to filter clayey sludge: an experimental study. Geotextiles and $\begin{array}{lllllll}\text { Geomembranes, } & \text { v. } & 42, & \text { n. } & 3, & \text { p. } & 214-223,\end{array}$ https://doi.org/10.1016/j.geotexmem.2014.03.002

CRITTENDEN, J. C.; TRUSSELL, R. R.; HAND, D. W.; HOWE, K. J.; TCHOBANOGLOUS, G. MWH's water treatment: principles and design. $3^{\text {rd }}$ ed. New York: John Wiley \& Sons, 2012. 1920 p. 1 v. 
DI BERNARDO, L.; DANTAS, D. A. Métodos e técnicas de tratamento de água. 2. ed. São Carlos: Rima/ABES, 2005.

DRISCOLL, J. et al. Comparison of 1-D and 2-D tests in geotextile dewatering applications. International Journal of Geosynthetics and Ground Engineering, v. 2, n. 3, p. 27, 2016. https://doi.org/10.1007/s40891-016-0068-0

EUROPEAN COMMITTEE FOR STANDARDIZATION. EN 13562: Geotextiles and geotextile-related products-Determination of resistance to penetration by water (hydrostatic pressure test). Brussels, 2000.

GUIMARÃES, M. G. A.; URASHIMA, D. C.; VIDAL, D. M. Dewatering of sludge from a water treatment plant in geotextile closed systems. Geosynthetics International, v. 21, n. 5, p. 310-320, 2014. https://doi.org/10.1680/gein.14.00018

ISO. ISO 12956: Geotextiles and geotextile - related products: Determination of the characteristic opening size. Geneva, 2010.

ISO. ISO 13320: Particle size analysis - Laser diffraction methods. Geneva, 2009.

ISO. ISO 2591-1: Test sieving - Part 1: Methods using test sieves of woven wire cloth and perforated metal plate. Geneva, 1988.

ISO. ISO 9863-1: Geosynthetics - Determination of Thickness at Specified Pressures - Part 1: Single Layers. Geneva, 2016.

ISO. ISO 9864: Geosynthetics - Test method for the determination of mass per unit area of geotextiles and geotextile-related products. Geneva, 2005.

LAMBE, T. W.; WHITMAN, R. V. Soil Mechanics. New York: John Wiley \& Sons, 1969. $576 \mathrm{p}$.

LAWSON, C. R. Geotextile containment for hydraulic and environmental engineering. Geosynthetics International, v. 15, n. $6, \quad$ p. 384-427, 2008. https://doi.org/10.1680/gein.2008.15.6.384

LIAO, K.; BHATIA, S. K. Geotextile tube: filtration performance of woven geotextiles under pressure. [S.1]: NAGS, 2005.

MINES JR., R. O. Environmental engineering: principles and practice. New York: John Wiley \& Sons, 2014.

MOO-YOUNG, H. K.; DOUGLAS A G.; XINGHUA, M. Testing Procedures to Assess the Viability of Dewatering with Geotextile Tubes. Geotextiles and Geomembranes, v. 20, n. 5, p. 289-303, 2002. https://doi.org/10.1016/S0266-1144(02)00028-6

MUTHUKUMARAN, A. E.; ILAMPARUTHI, K. Laboratory studies on geotextile filters as used in geotextile tube dewatering. Geotextiles and Geomembranes, v. 24, n. 4, p. 210 219, 2006. https://doi.org/10.1016/j.geotexmem.2006.03.002

RATNAYESURAJ, C. R.; BHATIA, S. K. Testing and analytical modeling of two-dimensional geotextile tube dewatering process. Geosynthetics International, v. 25, n. 2, p. 132-149, 2018. https://doi.org/10.1680/jgein.17.00038

REALI, M. A. P. Noções gerais de tratamento e disposição final de lodos de estações de tratamento de água. Rio de Janeiro: Rede Corporativa de Pesquisas, Projeto PROSAB, ABES, 1999. 
SATYAMURTHY, R.; BHATIA S. K. Effect of Polymer Conditioning on Dewatering Characteristics of Fine Sediment Slurry Using Geotextiles. Geosynthetics International, v. 16, n. 2, p. 83-96, 2009. https://doi.org/10.1680/gein.2009.16.2.83

SEGRÉ, G. F. A physicochemical evaluation of the compressibility and dewatering behavior of dredged sediments. 2013. 194 p. Theses (Master of Science in Civil Engineering) - Syracuse University, New York, 2013.

WEGGEL, J. R.; DORTCH, J. A model for filter cake formation on geotextiles: experiments. $\begin{array}{llllll}\text { Geotextiles and Geomembranes, v. 31, p. 62-68, } 2012 . & \text {. }\end{array}$ https://doi.org/10.1016/j.geotexmem.2011.10.003 